TURIZAM

Volume 13

Issue 1, 17-27 (2009)

\title{
Some Challenges of Creating a New Brand of Serbian Tourism: Case Study - The Republic of Užice
}

\author{
Miroslav Ivanović* \\ Bojan Milicević** \\ Received: July 2009 | Accepted: September 2009
}

\begin{abstract}
Throughout the national history, the southwestern Serbia has been considered as a strong communist center during the National War of Liberation under the authority of Tito, the Communist Party and the ideology of communism holders. This period is presented by the memorial complexes, squares, the Fires of Republic of Užice events, exhibitions in the rebellion museums, busts... These symbols of the past should not be exposed to oblivion, but must be freed of ideological stereotypes and megalomania.

The Republic of Užice, as tourist product, is not yet evaluated, nor covered by the range of additional contents that could be a part of the tourist offer in this area. Historical facts and legends create inexhaustible possibility for tourist promotion of the Republic of Užice.

This paper presents the possibility of creating a new brand in Serbian tourism and its significance for reviving neglected part of Serbian national history.
\end{abstract}

Key words: the Republic of Užice, branding, destination, cultural tourism, strategy

\section{Introduction}

The concept of tourism is difficult to be determined. In fact, there are as many definitions of tourism as those that deal with this phenomenon which significantly celebrates contemporary society. It is a part of our lives, no matter if we are agreed to it or not. It is hard to find someone who has never been a tourist. It intrigues and attracts our attention.

Indicator for the differentiation policy of the tourist product should be a system of motives that runs on tourist spending. But, despite of tourist affiliations, it is not pointless to offer the

* Department of Geography, Tourism and Hotel Management, Faculty of Science, University of Novi Sad, miroslav_ivanovic@yahoo.comtel: 031542 331, fax: 031524969

** Faculty of Organizational Sciences, University of Belgrade, bojan_milicevic@yahoo.com 
nature, history and culture of specific tourist destination, and use them for the promotion of tourism and local population life quality improvement.

\section{The Necessity of Creating a New Brand of Serbian Tourism}

Serbia has a minor role in the world's tourist market and the number of foreign visitors, as well as the income realized from tourism, is almost negligible. Serbia is not a suitable destination for the development of mass tourism, and especially not for international (Čerović, Petrović, 2006).

Frequent military conflicts and political boiling and disagreements are the image that the world has about Serbia (Gulan, 2006). In the European countries, Serbia is still not perceived by a product or destination, but by the bombardment in 1999 which is still the most recognizable brand. Most frequently mentioned people are Tito and contemporary politicians. Perception of the inhabitants of European and other countries has not been completely researched yet and it was impossible to determine precisely which are the biggest tourist potentials that could be branded.

Change of this image could contribute to the development of new products or branding existing ones, especially in the field of tourism as the most profitable field. In modern conditions of tourist business, many domestic destinations considered perspective within the development of local brands (Vesić, 2007). Therefore, it is necessary to analyze the character of implementation of local brand in the tourist business.

Branding is perhaps the most powerful marketing weapon available to contemporary destination marketers confronted by tourists who are increasingly seeking lifestyle fulfillment and experience rather than recognizing differentiation in the more tangible elements of the destination product such as accommodation and attractions (Morgan et al., 2007). Most destinations have superb five-star resorts and attractions, every country claims a unique culture, landscape and heritage, each place describes itself as having the friendliest people, and high standards of customer service and facilities are now expected. As a result, the need for destinations to create a unique identity - to differentiate themselves from their competitors - is more critical than ever.

\section{Brand and Branding of Tourist Destinations}

In the Dictionary of Business Terms, the brand is explained as "a sign, symbol or word by which the different products or services are determined. Brand is a broad term that includes all the brand names and trademarks" (Kotler, Armstrong, 2004).

According to Rita Clifton, a brand is: "a mixture of tangible and intangible attributes, symbolized in a trademark, which, if properly managed, creates influence and generates value" (Clifton, Maughan, 200o).

This definition truly captures the essence of a brand, and highlights the importance of brand management. Branding is about creating „value“, both for customers, and for the destination. This value stems from the products and services that companies create and bring to the market, but extends further to encompass added values derived from factors such as the brand-customer relationship, the brand's emotional benefits and its self-expressive benefits. 


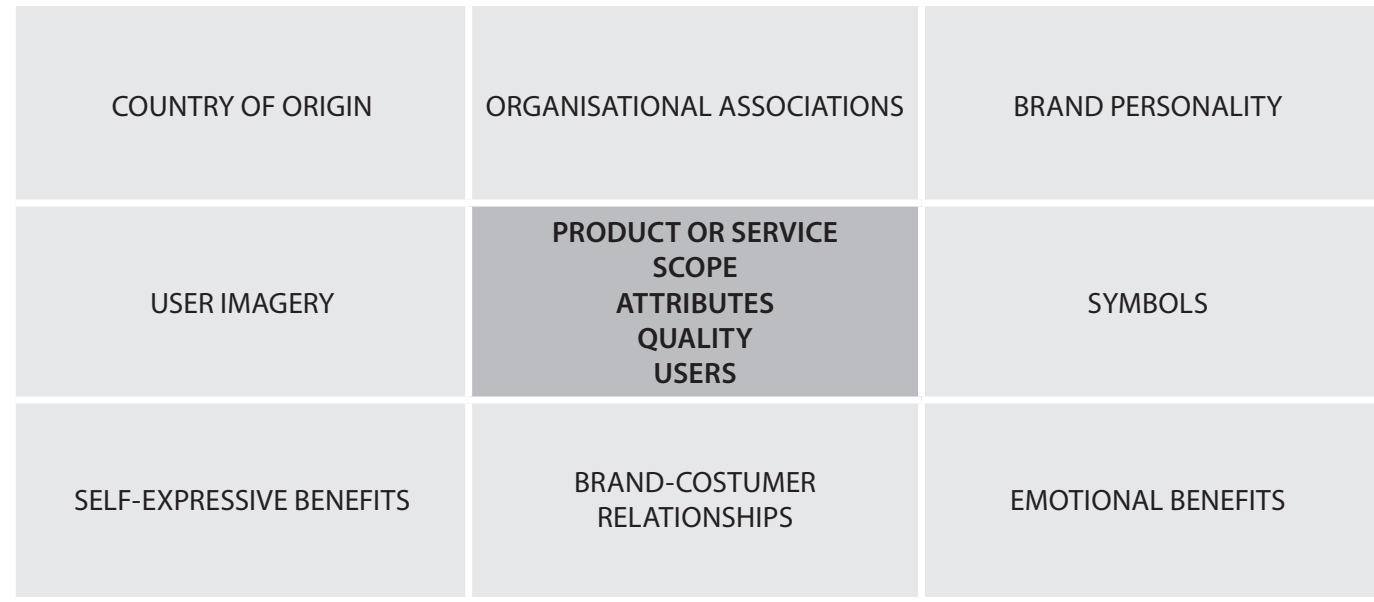

Figure 1. $A$ brand is more than product and service

Source: Adapted from Aaker, D. A, (1996), Building Strong Brands, New York: Free Press, p. 74

Tourist destination branding is a method of revealing the specifics of an environment, it makes the implementation of the tourist facilities and is presented to tourists. Tourist loyalty to a brand is reflected in the ability of the destination to content visitors' experience which is in line with their expectations (Tascu, Kozak, 2006).

A destination brand is a brand related to defined geographical region that's understood by tourists as an unique entity, with a political and legislative framework for tourism marketing and planning. Destinations are amalgams of tourism products, offering an integrated experience to the consumers. This amalgam of tourism products and services offered by a destination is consumed by tourists under the brand name of the destination during their period of staying (Buhalis, 200o). Brands incite beliefs, evoke emotions and prompt behavior. They have social and emotional value to users and speak to them (Kotler and Gertner, 2002).

The destination that have the character that is not sufficiently recognized, nor has placed in the service of the visual identity but is only used as a logo, decides to create a new visual identity.

\section{The Republic of Užice Phenomenon}

Significant events in the history of Serbia that are in tight connection with the development of the Republic of Užice took place in 1941, i.e. World War II. Hitler, without announcement of the war, in $6^{\text {th }}$ April 1941 attacked SFR Yugoslavia from all directions.

At the invitation of the Communist Party of Yugoslavia in Serbia has started the rebellion on $7^{\text {th }}$ July 1941. With the presence of a great number of people in Bela crkva, the people were called to fight against the occupiers. Rebellion culminated from September to November 1941, when a large free territory with center in Užice was formed, and there were established The Supreme Headquarters, Politburo Central Committee of the Communist Party of Yugoslavia (CC CPY) and the center of National War of Liberation (NWL) (Popović, 1978).

The Republic of Užice was territory liberated of the Nazis' occupation. It included territories of western Serbia and eastern Bosnia which were ruled by Yugoslav partisans.

The only connection between the Republic of Užice and modern state was dominion in temporarily liberated territory. It did not have permanent borders, and they were changing 


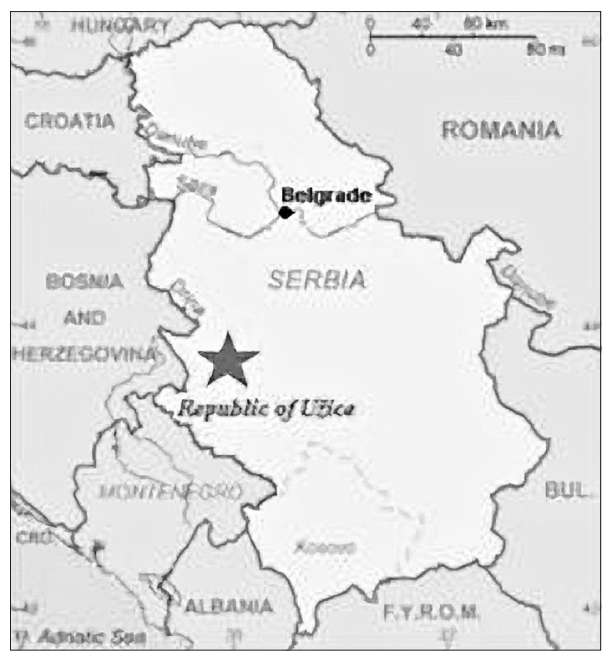

Figure 2. Position of the Republic of Užice in Serbia

Source: Adopted from www.serbianembassy.jp/english/mapofserbia.html; modified by the authors

almost daily, with every new partisans" or occupiers" offensive. In fact, the occupied area implied territory between the rivers:The Drina in the west,The Zapadna Morava in the east, The Skrapež in the north and The Uvac in the south. Thus formed state was lasting for only 67 days, and then fell into the hands of Wermacht, while the partisans were withdrawing back to Sandžak (Radovanovic, 1972).

According to these borders, the former territory of the Republic of Užice today is represented by the municipalities of Kosjerić, Užice, Bajina Bašta, Čajetina, Nova Varoš, Priboj and Prijepolje, in southwestern Serbia (about 4.312 square kilometers).

The importance of free territory in the western Serbia was multiple. Political leadership, the CPY, created a national army, built national authorities, conducted a military and political actions, elaborated plans for rebellions all over the Yugoslavia. Here there was a radio of the Supreme Headquarter and CPY, and the people called this free territory the Republic of Užice.

Rebellion and fights throughout the country were guided from Užice. Arms and ammunition were delivered to all parts of the country from partisan factory, so as clothing, shoes and more. Journal "Borba" was printed in Užice and distributed to the liberated and non-liberated territories.

National Movement of Liberation, from this period, especially in the region of Užice, was very important. According to Tito's words, it established the basis of our modern state was set in Užice. Partisan squads from the Republic of Užice entered the First and Second Proletarian Brigades and they led the fights for liberation of Kraljevo, Valjevo, Požega, Čačak, Kadinjača, etc. (Radovanovic, 1972).

These events must not remain forgotten because they represent a significant moment in our national history. All of this could be achieved by branding the concept of the Republic of Užice as a new tourist product. The idea of creating a tourist product based on the revival of long expired Republic of Užice is not yet evaluated in a right way, nor covered by the whole range of additional content that could be included in the tourist offer of this idea. Joining the past and the present, historical facts and legends create inexhaustible possibility of promotion of the Republic of Užice. 


\section{Preserved Heritage as a Basis for Branding}

There are several buildings where, at the time of the Republic of Užice, military and political leaderships were settled, and today they are under the protection of the state or have monumental values:

- The Rebellion Museum 1941 buildings,

- The State Mortgage Bank in Koštica,

- The General Hospital in Krčagovo,

- Residential building in Krčagovo (a former plantation),

- The building of the Municipal Assembly of Užice,

- The building of the Palace hotel,

- The factory Prvi Partizan in Krčagovo,

- The copper-works Čikiriza,

- Ineks Klekovaca Company building in Krčagovo,

- The memorial complex Kadinjača,

- The Mlekara company building (all in Užice municipality)

- Boško Buha memorial complex on Jabuka

- The ruins of the Partisans' hospital,

- Memorial complex 4th December,

- The building of School students in industry (all in Prijepolje municipality),

- The Villa Palisade in Zlatibor (Čajetina municipality),

- The memorial complex Žikica Jovanović Španac (Kosjerić municipality).

Memorial houses are special kind of monumental legacy that witnesses, mostly, about the places where famous personalities, who faught in The World War II, were born. These people provided a significant contribution to the liberation of the occupied territory and creation or implementation of certain political ideas of the time. Protected objects are the birth houses of:

- Savo Jovanović Sirogojno (1926-1944) in the village of Gornja Trnava (Čajetina)

- Miodrag Milovanović Lune (1921-1944) in Lunovo Selo (Užice).

- Petar Leković (1893-1942) in Svračkovo (Požega).

- Miodrag Bondžulić (1919-1943) in Otanj (Požega).

- Jevrem Lović (1919-1943) in Gornje Lopiže (Sjenica).

- Miloš Divac in Drenova (Prijepolje).

\section{The Tourist Exploitation of the Republic of Užice}

In the current tourist exploitation of the Republic of Užice heritage, there were sporadic attempts of its activation. Tourist organizations of southwestern Serbia recognized the importance of visual identity for the development and promotion of tourism in this area. This is one of the rare examples of understanding that the visual identity is "that something" which gives specials to the territory and defines it.

The tourist organization of Užice, in cooperation with the Tourist Organization of Western Serbia Region presented, on Tourism Fair 2009 in Belgrade, tourist arrangement the Republic of Užice Paths. It schedules tour of some of the attractiveness of the period. Symbols of the Republic of Užice were presented as well as official site www.uzickarepublika.com. The most important symbol of the Republic of Užice is Tito's bust, which was, at the end of ' 8 os of the 
last century, shifted from the main town square to the courtyard of the National Museum, where it is today.

Former building of the State Bank of the Kingdom of Yugoslavia after World War II has turned into a Rebellion museum 1941 (today National Museum Užice). Permanent and temporary museum settings are organized in the Museum, and despite the efforts of employees they record an unenviable visit. An exception is the organization of the National Museum Night 2009 event with exhibition Power of Youth that was consisted of exhibits, photographs, objects, documents related to the important action of the youth of Užice from 1945 to date, and a historical exhibition was followed by the musical-theater program of preschool children (www. nocmuzeja.org).

NWL memorial complexes are not today offered in organized tours because of current lack of material resources for the offer enrichment. Today, objects practically do not have owners, and the matter of their maintenance is not yet solved. Everything disclosed as the unique step in revolutionary tradition fostering is neglected (Ivanović, 2009).

Many buildings of this period, that had function of headquarters, hospitals, armories, etc. today are used as economic objects and none of them, including protected birth houses, have tourist value.

\section{Tourist Evaluation of Some Potentials of the Republic of Užice}

The essence of tourist evaluation is to determine the existing resources, which value sets objective and realistic possibilities of tourism development. The method used in this paper is a qualitative-quantitative method that is usually used in our scientific community.

Evaluation is done on the basis of the following criteria:

\begin{tabular}{c|l|l} 
Score & \multicolumn{1}{|c}{ Quality } & \multicolumn{1}{c}{ Description } \\
\hline 1 & unsatisfactory & not for the tourist site \\
\hline 2 & meets & the local tourist importance \\
\hline 3 & good & a regional significance \\
\hline 4 & very good & spread regional importance \\
\hline 5 & excellent & an international tourist significance
\end{tabular}

The fact is that the evaluation process is subjective, and in this evaluation experts of different scientific disciplines (Master in ethnology-anthropology, Bachelor in geography and Master in Tourism) participated.

The selection of the elements of the tourist evaluation is important as the evaluation itself.

We formed the set of elements:

1. General elements:

A. Micro location position and the availability (the position in the narrow geographical area, i.e. the settlement, closeness to roads)

B. Tourist evaluation of environment (type of geographical area, diversity, preservation of nature and environmental arrangement)

C. Tourist equipment (Accommodation and catering facilities, shops, souvenir shops, information tables, fountain, benches, restrooms)

D. Harmony of the tourist wealth (its position in relation to other tourist values in the environment). 
2. Additional elements:

E. Artistic value (an esthetic quality, cultural and historical importance) and

F. Cultural and historical significance of (history of place and its role in the past)

Table 1. Tourist evaluation of some monuments of the Republic of Užice

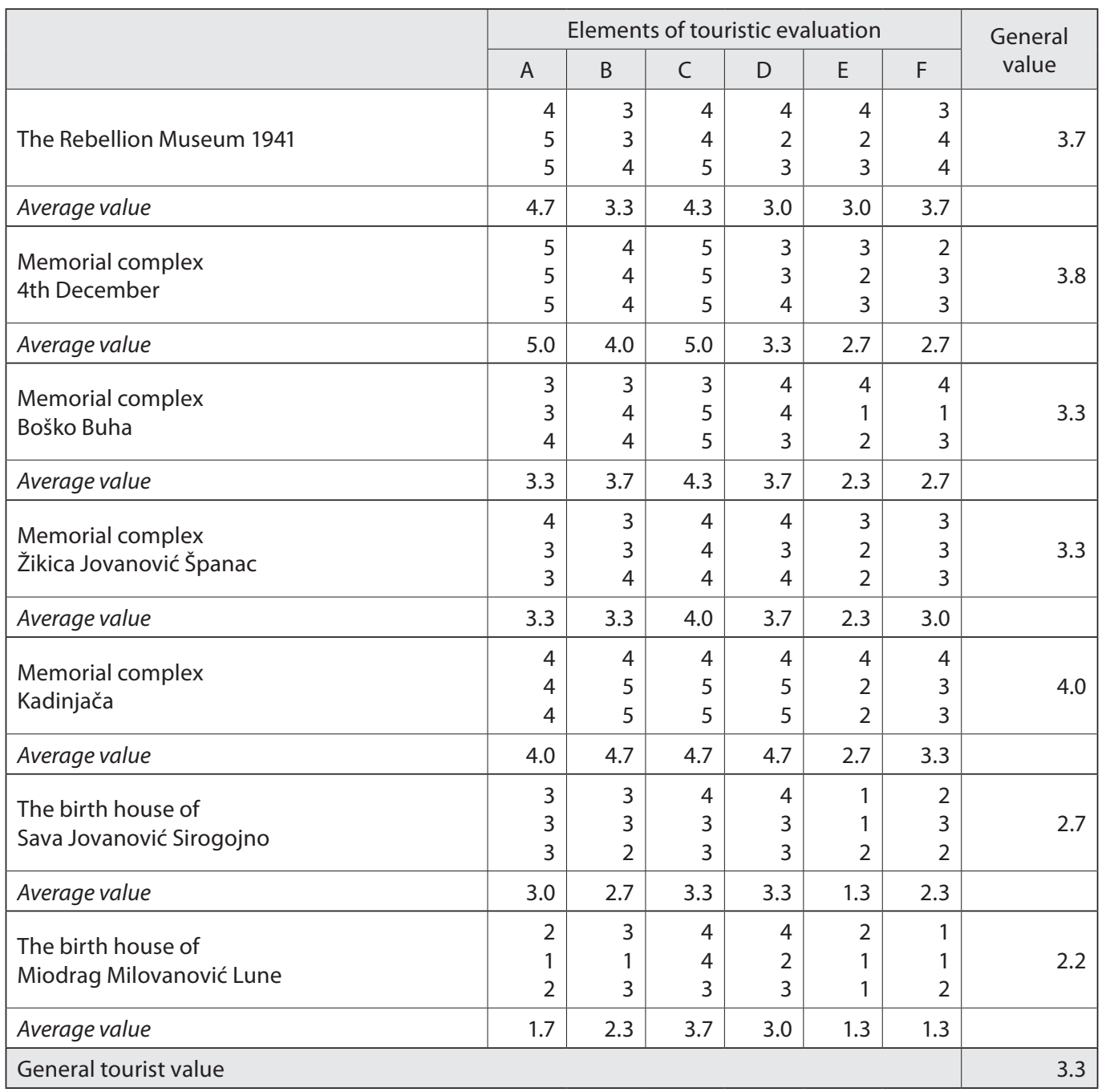

Source: Adopted from Ivanović, M. (2008), Cultural Tourism in Zlatibor County, Master work, FNS, Novi Sad, p. 164

General tourist value of listed monuments is 3.3 and it indicates their good quality and gives them the regional importance.

Most of the cultural goods of this group consist memory features from the NLW, and their average score is the result of the growing rejection of this period from social consciousness. The memorial features are characterized by poor availability, dilapidation and lack of sites in the tourist wealth harmony (average value 2.2-4.0).

Memorial characteristic, that is put apart from the others, is the Memorial complex Kadinjača that records score 4.0, and has wide regional character. Despite the bad tourist sites 
and insufficient equipment harmony with tourist wealth, Kadinjača is considered to have an exceptional cultural and historical significance and high artistic value.

Memorial houses have mostly local tourist importance, even though they are objects where the prominent fighters for the liberation were born or lived. These objects characterize mainly disrepair and full cut out from the tourist offer. Creation of adequate memorial collections and their organization in these facilities, would increase their tourist value, and, at least in some measure, would increase their opportunity to become part of tourist offer in Užice region.

Cultural and historical monuments were made at the time of historical events or later as a memory of the events and personalities. Their tourist activities can be enriched with various events and stage effects.

\section{Possible Branding Strategy of the Republic of Užice}

Brand orientation is a strategy of survival for tourist destinations facing the threats of decreasing product divergence, increasing media costs and integration of markets. The idea behind the strategy is to turn these threats into opportunities by focusing a destination's operations on competing with brand products.

According to Urde (1994) branding should contain a few steps:

(1) Making brand issues management issues: Managing a brand-oriented destination involves organizing and controlling the operations in such a way that an attractive added value can be created. The aim is that this should be accomplished with unchanged or increased total brand equity (Aaker, 1991). For instance, brands are still frequently reduced to be a tactical tool in the hands of the product manager in his sales efforts. The first step toward brand orientation must be the making of brand issues the management issues.

(2) Developing a brand vision: Brand-oriented destinations do not follow the development of brands, they spearhead it. The brand vision is their way of describing their long-term goals. The ambitions for the prioritized brands are concentrated in the vision, which thereby becomes a guiding-star. A well-defined vision also specifies the relationships within the brand-oriented destination. Such a brand vision, created by the management, allows all efforts and energy to be concentrated on its realization (Murphy, 1990).

(3) Making an inventory of destination's brands and patents: The exclusive proprietary right to brands and patents forms the basis of brand orientation. These intangible assets provide protection for the destination's market investments, brand protection especially so, not being limited in time (Cohen, 1991). Brand and patent protection, actively pursued, is a natural step toward brand orientation. It is therefore advisable to make an inventory of destination's intangible assets.

(4) Definition of destination's added value: In a competitive situation, it is impossible to be everything to everybody. Therefore, it is necessary to position the destination and its brands by means of added value. Quality is in many cases the basis of added value, but it needs to be further defined. In many markets, high quality is not a competitive advantage but a prerequisite for entering the competition. Hence, an attractive added value should be defined and linked to the destination and its brand products.

(5) Formulating a branding strategy: A branding strategy describes how the destination's brands should be used and organized, whereby the relationship between destination name and brand name is also determined (Doyle, 1992). Today, the branding strategies of many 
destination are inefficient, ineffective and unnecessarily complicated. Consequently, a branding strategy should be formulated based on the brand vision.

(6) Synchronization of communication: The image of the brand-oriented destination is a reflection of all its actions. Accordingly, it is vital that all its operations and all communication are synchronized in accordance with the brand vision. Uniformed, harmonized and consistent communication with the target group should be strived for.

(7) Investment in marketing activities which build and enhance the brands: Coordination of communication in a brand-oriented destination means that the individual parts (i.e. trademark, positioning, destination identity and product) enhance the whole, improving the conditions for effective market investments. Continuity is crucial.

(8) Development competence for successful brand orientation: Brand orientation is a choice of strategy, in many destinations determining their competitive strength and thereby also their prospects of survival in the long term. Increased awareness of brands and their potential is important to meet future competition. Competence in the area of strategic brand management should therefore be further developed to enable successful brand orientation.

\section{Branding Steps}

Creation and development of a brand includes four primary phases:

1. Establishment of cooperation between the stakeholders: For more efficient creation of tourist products, the first task is to establish cooperation between those entities that would find a common interest in the development of tourist products based on the image of Josip Broz Tito. It is essential that cooperation include representatives of tourist organizations of southwestern Serbia, the non-governmental sector and cultural institutions in order to identify the basic guidelines and define activities of the tourist product formation.

2. Formation of the tourist product - a significant activity that leads to the materialization of all the individual proposals. Efficient implementation of these ideas would contribute to:

- Souvenir making: the variety of tourist souvenirs: pendants, miniature weapons, CDs and publications depicting the history of the Republic of Užice, presentations of the tourist and other similar products.

- Event activities: development of event forms of tourism, along with high degree of animation of tourists and visitors.

- Information network: posting interesting billboards along main roads, as well as the informational panels to clearly show the interesting tourist products that should not be missed. By creating thematic routes and placing the informational signals, potential tourists would have the opportunity to walk through the nature and learn more about this tourist phenomenon.

3. Marketing activities include cooperation with the media. First of all, the basic task is directed to the fact that the first participants in the presentation of tourist products have to be journalists and other representatives of media outlets in order to present ideas based on the image of Josip Broz Tito, and free territory. After that, it is necessary to present the product to the tourist market, which will be achieved through active participation of the tourist organizations on fairs, congresses and other meetings of importance for the promotion.

4. Realization, control and development of tourist products include activities that would contribute to the further tourist product development. 


\section{The Positive Effects of Strategy Implementation}

According to the Tourism Strategy of the Republic of Serbia (2006), real positive changes, that could be expected, are:

Creating and branding a new tourist product will accelerate the strengthening of position of Užice region in Serbian tourist industry. It is necessary to create and maintain brand awareness in tourists' perception. Creating and realizing the Republic of Užice concept would have significant influence on young population who would become aware of this part of the history that is unfairly neglected in the past years in former Yugoslavia territory.

As this kind of tourism belongs to the cultural tourism, quality approach to it could attract a significant number of foreign tourists, primarily from the former Yugoslav republics.

This would estimate a possibility for activating the additional content that would help in affirmation of this idea. Implementation of additional content and ideas such as thematic excursions, interesting souvenirs, lectures, animation programs, multimedia, etc., would complete the tourist product. Oblivion and unkempt monuments from the NWL would be restored to life.

Further positive effect of the Republic of Užice would be dislocation of tourist "hot spots". For example, this would dislocate tourist demand from the centre of Zlatibor to the areas connected with the Republic of Užice. This could change the profile of future tourists and would contribute to the development of educational tourism, especially for elementary aged children.

Creating a new brand and its implementation, would activate local community through the adaptation of rural households which could include domestic production system in the tourist product encouraging business through the offer of tourist services to interested tourists.

\section{Conclusion}

The continental areas in Serbia need adequate tourist infrastructure construction for the dynamic development of tourism. It is necessary to determine the tactics for Serbian destinations to become highly respected destinations of preserved natural and cultural values. Serbia lacks well established brands, which means that we should start with the process of marking the different tourist products.

The conclusion is that the existing communism heritage in Serbia has to be restored and formed in the way that is acceptable for tourists' expectations. It considers creating the Republic of Užice themed cultural routes, organizing temporarily exhibitions that represent events, leaders, lifestyle etc. from this period. The help in developing the brand would be an activation of all resources of cultural heritage that are, or could be, related with the Republic of Užice. Stronger effect on tourists' experience and local economy, would be achieved by manufacturing and selling various souvenirs with the Republic of Užice logo, and, also, by organizing events with high level of tourist animation.

This model should be applied to the existing cultural heritage of this period and other forms of cultural identity in Serbia. This could be a significant prerequisite for a new model of cultural tourism that could be the attraction for young people and nostalgia of Tito's time. 


\section{References}

Aaker, D. A, (1996). Building Strong Brands, New York: Free Press.

Aaker, D. A. (1991). Managing Brand Equity, The Free Press, New York, NY.

Buhalis, D. 20oo. Marketing the competitive destination of the future, Tourism Management 21, 97-116.

Clifton, R., Maughan, E. (200o). The Future of Brands, Macmillan Press Ltd., London

Cohen, D. 1991. Trademark Strategy Revisited. Journal of Marketing 55, July, 46-59.

Čerović, S. Petrović, P. 2006. Determining the priorities of the development of Serbian tourism, Scientific Journal Turizam 10, 141-144.

Doyle, P. 1992. Building Successful Brands. Journal of Consumer Marketing 2, 5-19.

Gulan, B. 2006. Successful with its own brand. Magazine Lideri 4, 10-13, available at http:// www.liderdirektor.com/download/lideri4.pdf

http://www.nocmuzeja.org/2009/Snaga-mladosti

http://www.serbianembassy.jp/english/mapofserbia.html

Ivanović, M. (2008). Cultural Tourism in Zlatibor County, Master work, Department of geography, tourism and hotel management, Novi Sad

Ivanović, M. (2009). Cultural Heritage in the Tourism of Southwestern Serbia, Zadužbina Andrejević, Belgrade

Kotler, F., Armstrong, G. (2004). Principles of Marketing, Pearson, Prentice Hall

Kotler, P. Gertner, D. 2002. Country as brand, product and beyond: A place marketing and brand management perspective, Journal Brand Management 9, 4-5, 249-261.

Ministry of Trade, Tourism and Services (2006). Tourism Strategy of the Republic of Serbia, Belgrade, Serbia

Morgan, N., Pritchard, A., Pride, R. (2004). Destination branding: Creating the unique destination proposition (2nd ed.), Oxford: Butterworth-Heinemann.

Murphy, J. (1990). Brand Strategy, A Director Book, London.

Popovic, M. (1978). Tito and the Republic of Užice, The Republic of Užice, Bulletin of works, Export-press, Belgrade.

Radovanovic, J. (1972). 67 days of the Republic of Užice, Military book "National Army", Belgrade.

Tasci, A., Kozak, M. (2006). Destination brands vs. destination images: Do we know what we mean. Journal of Vacation Marketing.

Urde, M. (1994). Brand Orientation - A Strategy for Survival. Journal of Consumer Marketing $11(3), 18-32$.

Vesić, D. (2007). The development of trademark and global competitiveness in the tourism. Scientific Journal Turizam, 11,183-186. 